\title{
Sources of non-fossil-fuel emissions in carbonaceous aerosols during early winter in Chinese cities
}

\author{
Di Liu ${ }^{1}$, Jun Li ${ }^{1}$, Zhineng Cheng ${ }^{1}$, Guangcai Zhong ${ }^{1}$, Sanyuan Zhu ${ }^{1}$, Ping Ding ${ }^{2}$, Chengde Shen ${ }^{2}$, Chongguo Tian ${ }^{3}$, \\ Yingjun Chen ${ }^{4}$, Guorui Zhi ${ }^{5}$, and Gan Zhang ${ }^{1}$ \\ ${ }^{1}$ State Key Laboratory of Organic Geochemistry, Guangzhou Institute of Geochemistry, Chinese Academy of Sciences, \\ Guangzhou 510640, China \\ ${ }^{2}$ State Key Laboratory of Isotope Geochemistry, Guangzhou Institute of Geochemistry, Chinese Academy of Sciences, \\ Guangzhou 510640, China \\ ${ }^{3}$ Key Laboratory of Coastal Environmental Processes and Ecological Remediation, Yantai Institute of Coastal Zone Research, \\ Chinese Academy of Sciences, Yantai 264003, China \\ ${ }^{4}$ State Key Laboratory of Pollution Control and Resources Reuse, Key Laboratory of Cities' Mitigation and Adaptation to \\ Climate Change, College of Environmental Science and Engineering, Tongji University, Shanghai 200092, China \\ ${ }^{5}$ State Key Laboratory of Environmental Criteria and Risk Assessment, Chinese Research Academy of Environmental \\ Sciences, Beijing 100012, China
}

Correspondence to: Jun Li (junli@gig.ac.cn)

Received: 12 April 2017 - Discussion started: 16 May 2017

Revised: 6 August 2017 - Accepted: 8 August 2017 - Published: 27 September 2017

\begin{abstract}
China experiences frequent and severe haze outbreaks from the beginning of winter. Carbonaceous aerosols are regarded as an essential factor in controlling the formation and evolution of haze episodes. To elucidate the carbon sources of air pollution, source apportionment was conducted using radiocarbon $\left({ }^{14} \mathrm{C}\right)$ and unique molecular organic tracers. Daily $24 \mathrm{~h} \mathrm{PM}_{2.5}$ samples were collected continuously from October 2013 to November 2013 in 10 Chinese cities. The ${ }^{14} \mathrm{C}$ results indicated that non-fossil-fuel (NF) emissions were predominant in total carbon $(\mathrm{TC}$; average $=65 \pm 7 \%$ ). Approximately half of the EC was derived primarily from biomass burning $(\mathrm{BB})$ (average $=46 \pm 11 \%$ ), while over half of the organic carbon (OC) fraction comprised NF (average $=68 \pm 7 \%$ ). On average, the largest contributor to TC was NF-derived secondary $\mathrm{OC}$ ( $\left.\mathrm{SOC}_{\mathrm{nf}}\right)$, which accounted for $46 \pm 7 \%$ of TC, followed by SOC derived from fossil fuels (FF) $\left(\mathrm{SOC}_{\mathrm{f}} ; 16 \pm 3 \%\right), \mathrm{BB}$-derived primary $\mathrm{OC}\left(\mathrm{POC}_{\mathrm{bb}}\right.$; $13 \pm 5 \%$ ), POC derived from FF ( POC $_{\mathrm{f}} ; 12 \pm 3 \%$ ), EC derived from $\mathrm{FF}\left(\mathrm{EC}_{\mathrm{f}} ; 7 \pm 2 \%\right)$ and $\mathrm{EC}$ derived from $\mathrm{BB}\left(\mathrm{EC}_{\mathrm{bb}}\right.$; $6 \pm 2 \%)$. The regional background carbonaceous aerosol composition was characterized by NF sources; POCs played a major role in northern China, while SOCs contributed more in other regions. However, during haze episodes, there were
\end{abstract}

no dramatic changes in the carbon source or composition in the cities under study, but the contribution of POC from both FF and NF increased significantly.

\section{Introduction}

Recently, a wide range of fine particle $\left(\mathrm{PM}_{2.5}\right)$ pollution has affected northern, central and southern China, particularly on haze days, which has had significant effects on air quality, atmospheric visibility and public health, and caused extensive public and scientific concern (Liu et al., 2013; Wang et al., 2014). Haze events in Chinese urban areas, especially in megacities, have become a common phenomenon, appearing in every season, because of large and intensive pollutant emissions and unfavorable meteorological conditions (He et al., 2014; X. G. Liu et al., 2013). Generally, heavy and serious haze pollution outbreaks start at the beginning of winter.

Carbonaceous aerosols are the important component of $\mathrm{PM}_{2.5}$ ( 20-80\%) (Rogge et al., 1993; He et al., 2004; Dan et al., 2004; Kanakidou et al., 2005) and are regarded as essential for controlling the formation and evolution of haze episodes. Relatively high concentrations of carbona- 
ceous aerosols have been observed during typical haze days in northern, southern and central China (Zhao et al., 2013; Deng et al., 2008; Zhang et al., 2014). Generally, carbonaceous aerosols (total carbon, TC) can be divided into elemental carbon (EC) and organic carbon (OC) according to their different physical and chemical properties (Krivácsy et al., 2001; Kleefeld et al., 2002). EC is formed either from biomass burning (BB; e.g., wood fires, heating) or fossil fuel combustion (FF; e.g., vehicle or industry emissions such as coal combustion), and can be used as a tracer for primary combustion-generated OC because primary OC and EC are mostly emitted from the same sources (Turpin and Huntzicker, 1995; Strader et al., 1999). OC can be directly derived from primary emissions (primary OC; $\mathrm{POC}$ ), or formed through oxidation of reactive organic gases followed by gasto-particle conversion in the atmosphere (secondary OC; SOC) (Choi et al., 2012; Subramanian et al., 2007). Moreover, further subcategories of OC exist, including watersoluble organic carbon (WSOC) and water-insoluble organic carbon (WINSOC), which are distinguished on the basis of water solubility; these may be essential for assessing the different sources of $O C$ emissions during haze episodes, since WSOC is a proxy for SOC and BB OC, while a large fraction of WINSOC is from POC (Weber et al., 2007; Docherty et al., 2008; Mayol-Bracero et al., 2002; Huang et al., 2014).

Several methods have been introduced to identify and quantify OC emission sources, such as the use of organic molecular tracers (Simoneit et al., 1999), receptor models (positive matrix factorization, PMF; chemical mass balance, CMB) (Singh et al., 2017; Bove et al., 2014; Marcazzan et al., 2003), and dispersion models (Colvile et al., 2003); however, their reliability is limited by their low atmospheric lifetimes, in turn due to chemical reactivity and highly variable emission factors (Fine et al., 2001, 2002, 2004; Gao et al., 2003; Hedberg et al., 2006; Robinson et al., 2006). Recently, radiocarbon $\left({ }^{14} \mathrm{C}\right)$ analysis has been used as a powerful tool for facilitating the direct differentiation of non-fossilfuel (NF) carbon sources from fossil fuel (FF) sources, because ${ }^{14} \mathrm{C}$ is completely absent from $\mathrm{FF}$ carbon (e.g., diesel and gasoline exhaust, coal combustion), whereas NF carbon (e.g., biomass burning, cooking and biogenic emissions) shows a high contemporary ${ }^{14} \mathrm{C}$ level (Szidat et al., 2009). Hence, ${ }^{14} \mathrm{C}$ measurements can provide information about the contributions of FF, BB and biogenic emissions to carbonaceous aerosols. Numerous studies have been performed at urban sites and background sites to assess carbonaceous aerosol sources. For example, contemporary carbon was the dominant pollutant in carbonaceous aerosols at a background sites such as Ningbo and Hainan stations (Liu et al., 2013; Zhang et al., 2014). In urban sites, the relative carbon contributions have shown a significant seasonal difference (Yang et al., 2005; Chen et al., 2013; Liu et al., 2014a; Zhang et al., 2014, 2017). A combination of ${ }^{14} \mathrm{C}$ analysis and organic tracer determination allows for more detailed source apportionment of carbonaceous aerosols (Gelencsér et al., 2007;

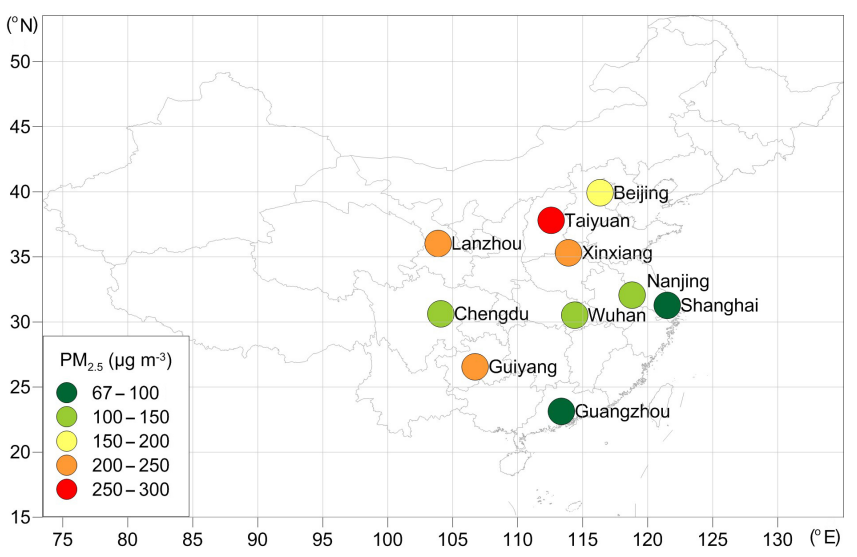

Figure 1. Geographic locations of the 10 Chinese sampling sites. The averages of monitored $\mathrm{PM}_{2.5}$ concentrations (daily resolution, $n=31$ for each site) during sampling campaign are shown in color plots.

Ding et al., 2008; Lee et al., 2010; Yttri et al., 2011; Zong et al., 2016; Liu et al., 2016a; Zhang et al., 2014).

In this study, sampling was conducted in 10 typical Chinese cities during early winter, when heavy haze pollution frequently occurs. Carbonaceous aerosols, including different carbon fractions such as WSOC, WINSOC and EC, along with water-soluble inorganic ions and organic tracers (i.e., anhydrosugars) were analyzed in $\mathrm{PM}_{2.5}$ samples. In particular, anhydrosugars such as levoglucosan are used as a molecular marker to indicate biomass-burning emissions. The combination of ${ }^{14} \mathrm{C}$ analysis and the concentration of levoglucosan has offered new insights into the detailed sources of carbonaceous aerosols. Therefore, source apportionment of carbonaceous aerosols was performed using a source apportionment model based on the ${ }^{14} \mathrm{C}$ results and measured chemicals.

\section{Materials and methods}

\subsection{Aerosol sampling}

Daily $24 \mathrm{~h} \mathrm{PM}_{2.5}$ samples were collected continuously on the rooftops of institutes in 10 Chinese cities (Fig. 1) from October 2013 to November 2013. In total, 292 aerosol samples, including 10 field blanks, were collected on preheated $\left(450{ }^{\circ} \mathrm{C}\right.$ for $\left.5 \mathrm{~h}\right)$ quartz fiber filters $(8 \times 10$ in.; Whatman, UK) using a high-volume sampler with a flow rate of $0.3 \mathrm{~m}^{3} \mathrm{~min}^{-1}$. The filters were then wrapped in aluminum foil, packed into airtight plastic bags, and stored at $-20^{\circ} \mathrm{C}$ in a refrigerator until analysis. $\mathrm{PM}_{2.5}$ mass concentrations were determined gravimetrically by state regulatory agencies. All samples were analyzed for OC and EC, and 20 samples, including two filters based on the $\mathrm{PM}_{2.5}$ concentrations at each site, were selected for further chemical analysis. De- 
tails of the sampling information and meteorological parameters used during sampling are shown in the Supplement.

\subsection{Chemical analysis}

OC and EC were obtained with an offline carbon analyzer (Sunset Laboratory, Inc., USA) using the thermo-optical transmittance method (NIOSH 870). Water-soluble inorganic ions $\left(\mathrm{Na}^{+}, \mathrm{Cl}^{-}, \mathrm{Ca}^{2+}, \mathrm{Mg}^{2+}, \mathrm{K}^{+}, \mathrm{NH}_{4}^{+}, \mathrm{SO}_{4}^{2-}\right.$ and $\mathrm{NO}_{3}^{-}$) were analyzed with an ion chromatographer (83 Basic IC Plus, Metrohm, Switzerland). Anhydrosugars (levoglucosan, galactosan and mannosan) were analyzed by gas chromatography-mass spectroscopy (GC-MS) (7890-5975; Agilent) using a capillary column (DB-5MS; $30 \mathrm{~m}, 0.25 \mathrm{~mm}$, $0.25 \mu \mathrm{m})$. Analysis methods related to OC and EC, watersoluble inorganic ions (Wang et al., 2012) and anhydrosugars (Liu et al., 2014a; 2014b) are presented elsewhere and a detailed analytical procedure and method are available in the Supplement.

\subsection{Separation of carbon species}

A punched section of filtrate was cut and sandwiched in a filtration unit, then extracted with $100 \mathrm{~mL}$ ultra-pure water (18.2 M $\Omega$ ). WSOC species were quantified using a total organic carbon (TOC) analyzer (TOC-VCPH; Shimadzu, Japan). The punched filtrate was dried in a desiccator, wrapped in aluminum foil and then stored in a refrigerator. WINSOC and EC were obtained from the water-filtered sample with an offline carbon analyzer (Sunset Laboratory, Inc.) using the thermo-optical transmittance method (NIOSH 870).

\subsection{Radiocarbon measurements}

Isolation procedures for the ${ }^{14} \mathrm{C}$ measurements of WSOC, WINSOC and EC have been described previously (Liu et al., 2016). Two filters, based on the $\mathrm{PM}_{2.5}$ concentrations at each site, were used for ${ }^{14} \mathrm{C}$ determination of WSOC, WINSOC and EC, to distinguish between FF and NF emissions. To obtain the WSOC, WINSOC and EC fractions from a single punch filter, a circular section of the punch filter was clamped in place between a filter support and a funnel and then $60 \mathrm{ml}$ ultra-pure water was slowly passed through the punch filter without a pump, allowing the WSOC to be extracted delicately. WSOC was quantified as the total dissolved organic carbon in solution using a total organic carbon (TOC) analyzer (Shimadzu TOC_VCPH, Japan) following the nonpurgeable organic carbon protocol. WSOC solution was freeze-dried to dryness at $-40^{\circ} \mathrm{C}$. The WSOC residue was re-dissolved with $\sim 500 \mu \mathrm{L}$ of ultra-pure water and then transferred to a pre-combusted quartz tube, which was then placed in the freeze dryer. After that, the quartz tube was combusted at $850^{\circ} \mathrm{C}$. The remaining carbon on the filter was identified as WINSOC or EC by an OC / EC analyzer (Sunset, USA). After WSOC pretreatment and freeze drying, $\mathrm{OC}$ is oxidized to $\mathrm{CO}_{2}$ under a stream of pre-cleaned pure analytical grade $\mathrm{O}_{2}\left(99.999 \%, 30 \mathrm{~mL} \mathrm{~min}^{-1}\right)$ during the pre-combustion step at $340^{\circ} \mathrm{C}$ for $15 \mathrm{~min}$. Before the OC is oxidized, the sample is first positioned in the $650^{\circ} \mathrm{C}$ oven for about $45 \mathrm{~s}$ of flash heating. This flash heating has the advantage of minimizing pre-combustion charring, since it reduces pyrolysis of OC. After the OC separation, the filters were removed from the system, placed into a muffle furnace at $375^{\circ} \mathrm{C}$, and combusted for $4 \mathrm{~h}$. The filters were then quickly introduced back into the system and oxidized under a stream of pure oxygen at $650^{\circ} \mathrm{C}$ for $10 \mathrm{~min}$ to analyze the $\mathrm{EC}$ fraction. Finally, the corresponding evolved $\mathrm{CO}_{2}$ (WSOC, WINSOC, and EC) was cryo-trapped, quantified manometrically, sealed in a quartz tube and reduced to graphite at $600{ }^{\circ} \mathrm{C}$ using zinc with an iron $(200 \mathrm{mg}$, Alfa Aesar, 1.5$3 \mathrm{~mm}, 99.99 \%$ ) catalyst for accelerator mass spectrometry (AMS) target preparation. Approximately $200 \mu \mathrm{g}$ of carbon was prepared for each carbon fraction.

All ${ }^{14} \mathrm{C}$ values were reported as the fraction of modern carbon $\left(f_{\mathrm{m}}\right)$ after correcting for fractionation with $\delta^{13} \mathrm{C}$. The degree of uncertainty in the ${ }^{14} \mathrm{C}$ measurements was in the range of $0.2-0.6 \%$. In this study, $f_{\mathrm{m}}$ was converted to the fraction of contemporary carbon $\left(f_{\mathrm{c}}\right)$ to eliminate the effects of nuclear bomb tests through application of conversion factors of $1.10 \pm 0.05$ for $\mathrm{EC}$ and $1.06 \pm 0.05$ for $2013 \mathrm{OC}$ data. Here, the $f_{\mathrm{m}}$ values of OC (OC $\left.=\mathrm{WSOC}+\mathrm{WINSOC}\right)$ and TC $(\mathrm{TC}=\mathrm{WSOC}+\mathrm{WINSOC}+\mathrm{EC})$ were calculated by isotopic mass balance. The uncertainties of $f_{\mathrm{nf}}$ (and $f_{\mathrm{m}}$ ) in WSOC, WINSOC, OC and EC were up to 20, 20, 15 and $15 \%$, respectively. The concentration in the field blank was negligible $\left(0.37 \pm 0.05 \mu \mathrm{g} \mathrm{cm}^{-2}\right.$; less than $5 \%$ carbon $)$ and no field blank subtraction was made for ${ }^{14} \mathrm{C}$ determination. The system blank $F^{14} \mathrm{C}$ was $0.0036(\mathrm{SD}=0.0001)$, which translated to a ${ }^{14} \mathrm{C}$ age of around 45000 years BP.

\section{Results and discussion}

\section{1 $\mathrm{PM}_{2.5}, \mathrm{OC}$ and $\mathrm{EC}$ concentrations and spatial distribution}

$\mathrm{PM}_{2.5}$ levels ranged from 21.9 to $482 \mu \mathrm{g} \mathrm{m}^{-3}$, with an average level of $178 \pm 103 \mu \mathrm{g} \mathrm{m}^{-3}$. A total of 98 and $81 \%$ of $\mathrm{PM}_{2.5}$ exceeded the First Grade National Standard $\left(35 \mu \mathrm{g} \mathrm{m}^{-3}\right)$ and Second Grade National Standard $\left(75 \mu \mathrm{g} \mathrm{m}^{-3}\right)$ of China, respectively, indicating relatively poor air quality during sampling days. The OC and EC levels ranged from 0.99 to $75.9 \mu \mathrm{g} \mathrm{m}^{-3}$ (average = $22.8 \pm 15.3 \mu \mathrm{g} \mathrm{m}^{-3}$ ) and $0.07-19.3 \mu \mathrm{g} \mathrm{m}^{-3}$ (average $=3.66 \pm$ $3.28 \mu \mathrm{g} \mathrm{m}^{-3}$ ), respectively; thus, OC and EC were major components of $\mathrm{PM}_{2.5}$, accounting for $13 \pm 8$ and $2 \pm 1 \%$ of $\mathrm{PM}_{2.5}$, respectively. The $\mathrm{OC}$ and EC levels in this study were generally higher than those recorded previously in more developed cities (e.g., New York, Los Angeles, Erfurt, Kosan) (Kam et al., 2012; Kim et al., 2000; Gnauk et al., 2005; Rat- 
Table 1. The $\mathrm{PM}_{2.5}$, OC and EC data used in this study (average \pm standard deviation; $\mu \mathrm{g} \mathrm{m}^{-3}$ ).

\begin{tabular}{lrrrrrr}
\hline Sites & $N$ & $\mathrm{PM}_{2.5}$ & OC & $\mathrm{EC}$ & $\begin{array}{r}\mathrm{OM}^{2} \mathrm{PM}_{2.5} \\
(\%)\end{array}$ & $\mathrm{OC} / \mathrm{EC}$ \\
\hline Beijing & 31 & $189 \pm 79$ & $26.5 \pm 12.5$ & $3.6 \pm 1.8$ & $24 \pm 4.6$ & $7.7 \pm 1.8$ \\
Xinxiang & 31 & $245 \pm 65$ & $29.3 \pm 11.7$ & $4.8 \pm 2.2$ & $21 \pm 4.9$ & $6.5 \pm 1.9$ \\
Taiyuan & 31 & $285 \pm 84$ & $37.3 \pm 15.5$ & $7.8 \pm 2.8$ & $23 \pm 4.4$ & $4.9 \pm 1.5$ \\
Lanzhou & 31 & $212 \pm 112$ & $21.4 \pm 9.1$ & $5.0 \pm 2.7$ & $19 \pm 3.9$ & $4.8 \pm 1.2$ \\
Guiyang & 30 & $227 \pm 77$ & $7.5 \pm 4.4$ & $0.76 \pm 0.5$ & $6.0 \pm 3.4$ & $11 \pm 4.4$ \\
Chengdu & 26 & $105 \pm 39$ & $17.7 \pm 8.1$ & $1.8 \pm 0.8$ & $28 \pm 4.8$ & $10 \pm 3.0$ \\
Wuhan & 22 & $123 \pm 49$ & $17.5 \pm 8.3$ & $2.0 \pm 1.2$ & $24 \pm 8.5$ & $9.6 \pm 2.7$ \\
Guangzhou & 28 & $85 \pm 32$ & $17.4 \pm 9.9$ & $2.3 \pm 1.8$ & $33 \pm 11$ & $8.1 \pm 2.4$ \\
Nanjing & 19 & $111 \pm 50$ & $18.8 \pm 8.7$ & $1.6 \pm 0.6$ & $28 \pm 9.3$ & $12 \pm 3.8$ \\
Shanghai & 27 & $68 \pm 43$ & $7.2 \pm 9.0$ & $1.0 \pm 0.9$ & $17 \pm 8.5$ & $7.4 \pm 3.0$ \\
\hline
\end{tabular}

tigan et al., 2010), indicating severe carbonaceous pollution and emphasizing the importance of restricting carbonaceous aerosols in China.

Northern China has high $\mathrm{PM}_{2.5}$ concentrations. As shown in Table 1 , the average $\mathrm{PM}_{2.5}$ concentrations in Beijing $\left(190 \pm 79 \mu^{-3} \mathrm{~m}^{-3}\right)$, Xinxiang $\left(245 \pm 65 \mu \mathrm{g} \mathrm{m}^{-3}\right)$, Taiyuan $\left(285 \pm 84 \mu \mathrm{g} \mathrm{m}^{-3}\right)$ and Lanzhou $\left(212 \pm 112 \mu \mathrm{g} \mathrm{m}^{-3}\right)$ were significantly higher than those in central and southern China (from $85 \mu \mathrm{g} \mathrm{m}^{-3}$ in Guangzhou to $123 \mu \mathrm{g} \mathrm{m}^{-3}$ in Wuhan). Shanghai, in the eastern coastal region, had the lowest average $\mathrm{PM}_{2.5}$ concentration $\left(67 \pm 43 \mu \mathrm{g} \mathrm{m}^{-3}\right)$. The ratio of total organic matter (TOM; $1.6 \times \mathrm{OC}+\mathrm{EC})$ to total fine particle mass ranged from 17.4 to $32.6 \%$, except in Guiyang. Cities in central and southern China, such as Chengdu, Wuhan, Nanjing, and Guangzhou, had a higher ratio of TOM to $\mathrm{PM}_{2.5}$ than other cities. Moreover, the OC/EC ratios in those cities were also higher, with values ranging between 8.1 and 12 . The spatial distribution pattern closely reflected energy consumption and regional climate differences. In particular, Guiyang, which is a developing city located on the western plateau, had a high level of $\mathrm{PM}_{2.5}\left(227 \pm 77 \mu \mathrm{g} \mathrm{m}^{-3}\right)$, comparable to that in northern China, but also had the lowest levels of OC and EC. Moreover, the TOM to $\mathrm{PM}_{2.5}$ ratio was only about $6.0 \%$. This indicates that there are different chemical sources in this developing city compared to megacities in China.

\subsection{Radiocarbon results: fraction of modern carbon $\left(f_{\mathbf{m}}\right)$}

Table 2 shows the proportion (\%) of NF sources in various carbon fractions. Overall, NF emissions represented a more significant proportion of the TC (average $=65 \pm 7 \%$; range: 50-79\%), at all sites, than FF sources, which underscores the importance of NF sources to carbonaceous aerosols during early winter in China.
EC is only formed by primary emissions, which are inert in ambient air and originate either from BB or FF combustion. In this study, about half of the EC was derived from BB in the 10 urban cities (average $46 \pm 11 \%$; range: $24-71 \%$ ), which represents a slightly higher proportion than that for the same cities in winter and spring but is similar to previous studies performed in cities in other countries (Szidat et al., 2009; Bernardoni et al., 2013). However, this result differs from those obtained in remote regions dominated by BB (Barrett et al., 2015; Zhang et al., 2014). Compared with other studies in China, the measured biomass burning contributions to EC in Beijing are relatively higher than those in the same city during winter (Zhang et al., 2014, 2015b). This is due to the fact that different approach we used for OC / EC separation, and sample selection in this study (selected two filter samples based on relatively lower and higher $\mathrm{PM}_{2.5}$ concentration for each site) because of limitations for ${ }^{14} \mathrm{C}$ analysis (i.e., the bulk samples required and the high $\operatorname{cost}$ for ${ }^{14} \mathrm{C}$ measurement). However, the result is similar to those using the same approach (Liu et al., 2016b; Zong et al., 2016). A larger contribution of BB to EC was found in central and western China (i.e., Beijing, Lanzhou, Chengdu and Guiyang) (49 $63 \%$ ), where Guiyang had the largest proportion of $\mathrm{BB}$ in EC $(63 \pm 12 \%)$, followed by Beijing $(50 \pm 2.0 \%)$, Chengdu $(50 \pm 1.8 \%)$, Wuhan $(48 \pm 10 \%)$ and Nanjing $(47 \pm 5 \%)$; this shows that there are large amounts of BB emissions (e.g., from biofuel burning and outdoor fires) in western and central China during early winter. This phenomenon was also found in central China during the severe haze episode that occurred over China in January 2013, which suggests that these massive BB emissions were generated indoors (i.e., from domestic heating and cooking) and thus could not be detected by MODIS (Liu et al., 2016a). Guangzhou had the lowest proportion of BB in EC ( $32 \pm 12 \%)$, suggesting that FF emissions (coal combustion and vehicle emissions) dominated in the Pearl Delta region. Similar to Guangzhou, Taiyuan and Xinxiang had lower proportions of BB in EC, of $36 \pm 11 \%$ and $37 \pm 1.7 \%$, respectively. High proportions of $\mathrm{BB}$ in EC are with the extremely high levels of BB tracers (levoglu- 


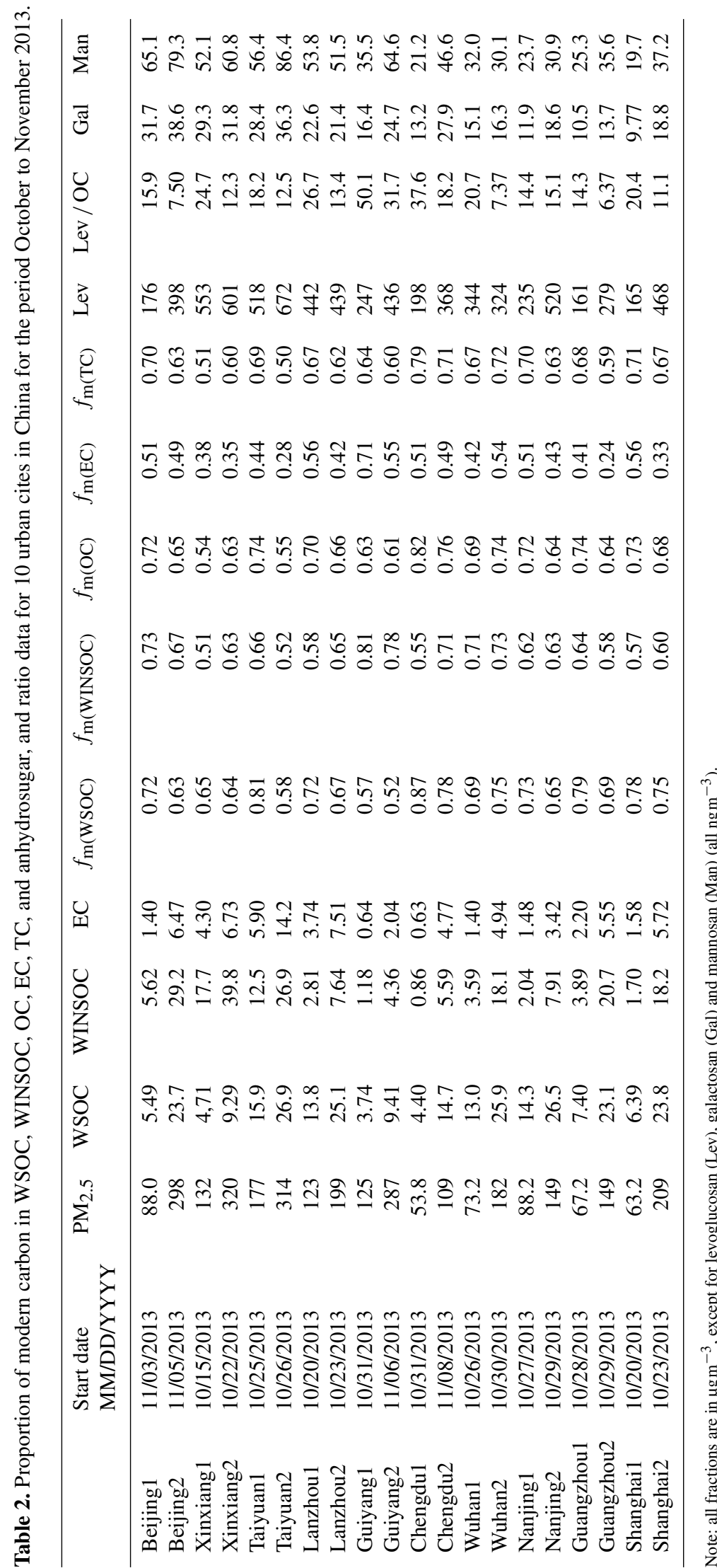


cosan). In this study, levoglucosan concentrations were in the range $161-672 \mathrm{ng} \mathrm{m}^{-3}\left(377 \pm 153 \mathrm{ng} \mathrm{m}^{-3}\right)$, and were significantly correlated with EC concentrations in $\mathrm{BB}(r=0.708$, $p=0.000)$.

Over half of the OC fraction was from NF sources at all sites (range: $54-82 \%$ ), with an average NF source contribution of $68 \pm 7 \%$, comparable to previous study reported in four Chinese cities during 2013 winter (Xi'an, Beijing, Shanghai and Guangzhou were 63, 42, 51, and $65 \%$, respectively) (Zhang et al., 2015a). Generally, the $f_{\mathrm{m}}$ spatial distribution of OC is similar to that of EC, with NF sources contributing more in central China. Here, OC was divided into WSOC and WINSOC, which has been separated with respect to fossil and NF sources. A large contribution of NF sources to WINSOC (64 $\pm 7 \%$ ) was observed in this study, comparable to previous studies performed in urban areas of Europe, e.g., Gothenburg (55 $\pm 8 \%$ ) and Zurich $(70 \pm 7 \%)$ (Szidat et al., 2009; Zhang et al., 2013). Moreover, the $f_{\mathrm{m}}$ values for WSOC $(70 \pm 8 \%)$ were slightly higher than those for WINSOC, which showed values comparable to those observed in European and American cities ( 70-85\%) (Weber et al., 2007; Szidat et al., 2009; Zhang et al., 2013). A higher $f_{\mathrm{m}}$ value indicated that, for WSOC, the contribution of NF emission sources was greater. WSOC is regarded as a mixture of SOC and BB-derived POC, whereas WINSOC is mainly composed of POC from FF combustion, $\mathrm{BB}$ and biogenic sources. In this study, the ratio of WSOC to OC increased significantly with an increase in the proportion of NF sources in OC $(r=0.531, p=0.016)$; this implies that POC from $\mathrm{BB}$ is more water-soluble, or that more NF-derived VOCs were involved in SOC formation.

\subsection{Source apportionment of different carbon fractions}

A source apportionment model for carbonaceous aerosols, including primary and secondary sources, was applied in this study using measured carbon fractions, anhydrosugars, and ${ }^{14} \mathrm{C}$ isotopic signals. Detailed information on this model has been provided previously (Liu et al., 2014a, 2016a).

Briefly, EC from FF combustion $\left(\mathrm{EC}_{\mathrm{f}}\right)$ and $\mathrm{BB}$-derived $\mathrm{EC}$ $\left(\mathrm{EC}_{\mathrm{bb}}\right)$ can be estimated using the following respective equations:

$\mathrm{EC}_{\mathrm{f}}=\mathrm{EC} \cdot\left(1-f_{\mathrm{c}}\right)$,

$\mathrm{EC}_{\mathrm{bb}}=\mathrm{EC} \cdot f_{\mathrm{c}}$.

Similar to EC, OC can be divided into FF OC $\left(\mathrm{OC}_{\mathrm{f}}\right)$ and $\mathrm{NF}$ $\mathrm{OC}\left(\mathrm{OC}_{\mathrm{nf}}\right)$ based on ${ }^{14} \mathrm{C}$ concentrations. $\mathrm{OC}_{\mathrm{nf}}$ consists of BB-derived primary OC $\left(\mathrm{POC}_{\mathrm{bb}}\right), \mathrm{NF}$-derived SOC $\left(\mathrm{SOC}_{\mathrm{nf}}\right)$ and biological primary carbon (BPC), such as spore and plant debris. BPC particles exist mainly in coarse fractions $(>2.5 \mu \mathrm{m})$ and only account for $\sim 1 \%$ of OC in $\mathrm{PM}_{2.5}$ (Guo et al., 2012). Thus, this carbon fraction was ignored in the present study. POC $_{\mathrm{bb}}$ can be semi-quantitatively estimated from Lev concentrations, due to its unique characteristic of originating from $\mathrm{BB}$, as follows:

$\mathrm{POC}_{\mathrm{bb}}=\mathrm{Lev} \cdot(\mathrm{OC} / \mathrm{Lev})_{\mathrm{bb}}$.

According to the levoglucosan/mannosan (Lev/Man; 17.4 \pm 5.9 ) and mannosan / galactosan (Man / Gal; 2.1 \pm 0.3 ) ratios obtained in this study, $7.76 \pm 1.47$ was adopted as the (OC / Lev) bb value (Liu et al., 2014a).

Thus, the $\mathrm{SOC}_{\mathrm{nf}}$ fraction can be estimated through subtraction:

$\mathrm{SOC}_{\mathrm{nf}}=\mathrm{OC}_{\mathrm{nf}}-\mathrm{POC}_{\mathrm{bb}}$.

FF-derived POC and SOC can be estimated by the following respective equations:

POC $_{\mathrm{f}}=$ WINSOC $\cdot\left(1-f_{\mathrm{c}}\right)$,
$\mathrm{SOC}_{\mathrm{f}}=\mathrm{WSOC} \cdot\left(1-f_{\mathrm{c}}\right)$.

Figure 2 shows the proportions of different carbon fractions, including $\mathrm{EC}_{\mathrm{f}}, \mathrm{EC}_{\mathrm{bb}}, \mathrm{POC}_{\mathrm{bb}}, \mathrm{POC}_{\mathrm{f}}, \mathrm{SOC}_{\mathrm{nf}}$ and $\mathrm{SOC}_{\mathrm{f}}$, in total carbon (TC) for the 10 urban cites during the sampling period. On average, the largest contributor to TC was $\mathrm{SOC}_{\mathrm{nf}}$, accounting for $46 \pm 7 \%$ of $\mathrm{TC}$, followed by $\mathrm{SOC}_{\mathrm{f}}$ $(16 \pm 3 \%), \mathrm{POC}_{\mathrm{bb}}(13 \pm 5 \%), \mathrm{POC}_{\mathrm{f}}(12 \pm 3 \%), \mathrm{EC}_{\mathrm{f}}(7 \pm$ $2 \%)$ and $\mathrm{EC}_{\mathrm{bb}}(6 \pm 2 \%)$. The proportion of primary sources $\left(\mathrm{POC}_{\mathrm{nf}}+\mathrm{POC}_{\mathrm{f}}+\mathrm{EC}_{\mathrm{nf}}+\mathrm{EC}_{\mathrm{f}}\right)$ (average $=38 \pm 9 \%$; range: $25-56 \%)$ was lower than that of secondary sources $\left(\mathrm{SOC}_{\mathrm{nf}}+\right.$ $\mathrm{SOC}_{\mathrm{f}}$ ) (average $=62 \pm 9 \%$; range: $35-83 \%$ ), which underlines the importance of SOC in carbonaceous pollution.

It should be noted that the model uncertainties in these contributions depended mainly on correction factors, such as the $(\mathrm{POC} / \mathrm{Lev})_{\mathrm{bb}}$ emission ratios for wood burning, and on conversion factors used for determining the $f_{\mathrm{c}}$ in ${ }^{14} \mathrm{C}$ analysis. Typical relative uncertainties were recently estimated, using a similar modeling approach, at 20-25\% for $\mathrm{SOC}_{\mathrm{nf}}$, $\mathrm{SOC}_{\mathrm{f}}, \mathrm{POC}_{\mathrm{bb}}$, and $\mathrm{POC}_{\mathrm{f}}$, and $\sim 13 \%$ for $\mathrm{EC}_{\mathrm{f}}$ and $\mathrm{EC}_{\mathrm{bb}}$ (Zhang et al., 2015a). A large fraction WINSOC can be from secondary organic aerosol as well. Hence, $\mathrm{POC}_{\mathrm{f}}$ is an upper limit of $\mathrm{POC}_{\mathrm{f}}$. $\mathrm{SOC}_{\mathrm{f}}$ may be overestimated if a small fraction (e.g., $<20 \%$ ) of WSOC is not secondary, so $\mathrm{SOC}_{\mathrm{f}}$ may be an upper limit. Meanwhile, $\mathrm{SOC}_{\mathrm{nf}}$ may also include other nonfossil sources such as cooking and biogenic emissions, however, they should be limited during wintertime (e.g., $<20 \%$ ). Therefore, our estimates of SOC many generally represent an upper limit but this will not change our conclusion towards the spatial distribution of SOC in China.

POC and EC aerosols are independent from atmospheric gas reaction conditions and thus directly reflect the characteristics of local emission sources. The total proportions of $\mathrm{EC}_{\mathrm{f}}$ and $\mathrm{POC}_{\mathrm{f}}$ ranged from 10 to $38 \%$, with an average of $19 \pm 9 \%$ for all sites. The total proportions of $\mathrm{EC}_{\mathrm{f}}$ and $\mathrm{POC}_{\mathrm{f}}$ in northern and southern China were greater than in western central and eastern coastal China, indicating a higher impact of FF on local air pollution in both regions. The ratios of $\mathrm{POC}_{\mathrm{f}}$ to $\mathrm{EC}_{\mathrm{f}}(0.66-3.32)$ were within the emission ratios between coal combustion (2.7-6.1) (Zhang et al., 2008) 

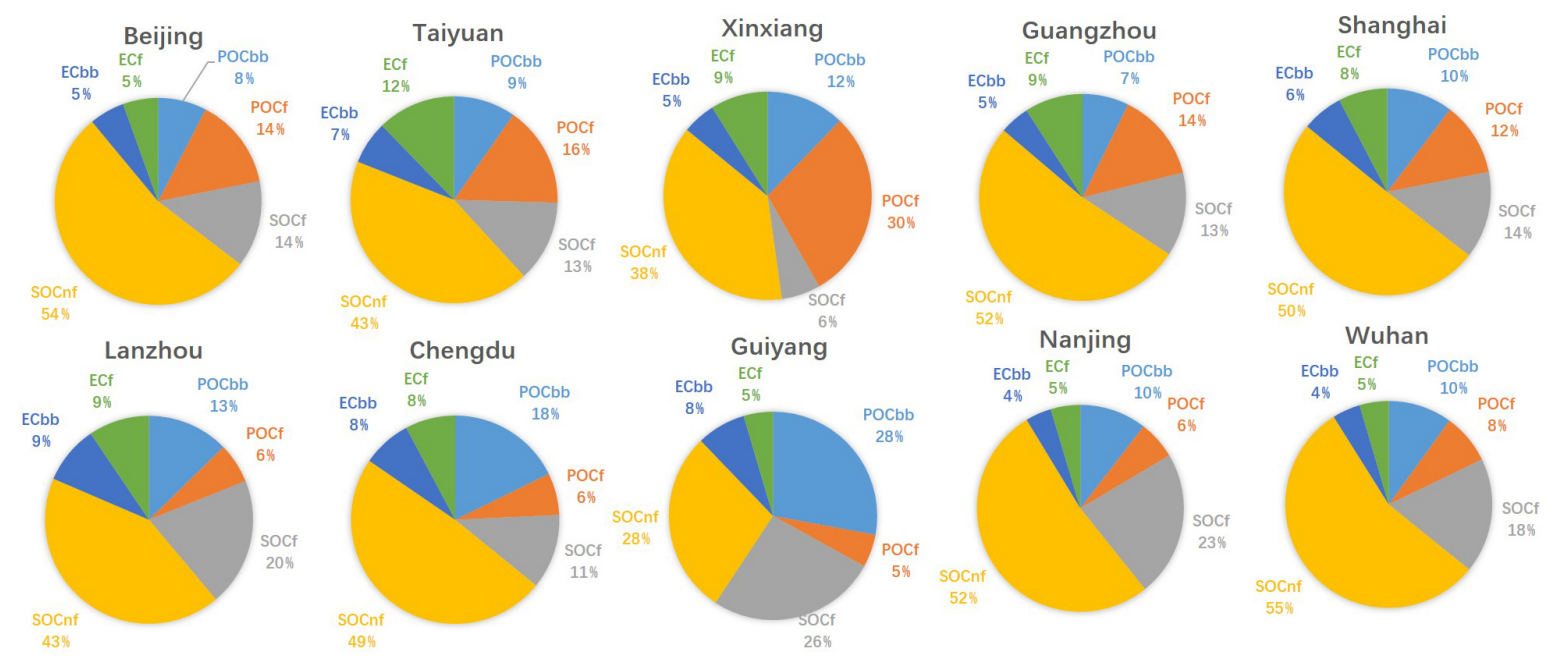

Figure 2. The proportions of different carbon fractions, including elemental carbon derived from fossil fuels $\left(\mathrm{EC}_{\mathrm{f}}\right)$, $\mathrm{EC}_{\mathrm{ferived}}$ from burning biomass $\left(\mathrm{EC}_{\mathrm{bb}}\right)$, BB-derived primary organic carbon $\left(\mathrm{POC}_{\mathrm{bb}}\right)$, POC derived from $\mathrm{FF}\left(\mathrm{POC}_{\mathrm{f}}\right)$, non-FF secondary $\mathrm{OC}\left(\mathrm{SOC} \mathrm{Cf}_{\mathrm{nf}}\right)$ and $\mathrm{SOC}$ derived from $\mathrm{FF}\left(\mathrm{SOC}_{\mathrm{f}}\right)$ in total carbon (TC) for 10 urban cites during the sampling period.

and traffic exhausts fumes (0.5-1.3) (Zhou et al., 2014; He et al., 2008), indicating that coal combustion and traffic exhaust fumes were the major primary sources at all sites. Beijing (2.6) and Xinxiang (3.3) were mainly dominated by coal combustion emissions. The total proportions of $\mathrm{EC}_{\mathrm{bb}}$ and $\mathrm{POC}_{\mathrm{bb}}$ ranged from 12 to $36 \%$, with an average of $19 \pm 8 \%$. West central cities, such as Lanzhou, Chengdu, Guiyang, Nanjing and Wuhan, had large proportions of $\mathrm{EC}_{\mathrm{bb}}$ and $\mathrm{POC}_{\mathrm{bb}}$ (average $=23 \pm 7 \%$; range: $14-36 \%$ ), which confirms the greater impact of $\mathrm{BB}$ on local air pollution in west central China; this should be considered when setting future limits for polluting corporations.

Total SOC in OC ranged from 42 to $84 \%$ (average $=$ $72 \pm 10 \%$ ) among the sites tested in this study, which is similar to recent studies, conducted in the haze period in China of January 2013, which used high-resolution aerosol mass spectrometry; i.e., 41-59\% (Sun et al., 2014) and 44-71\% (Huang et al., 2014) obtained from online and offline measurements, respectively. There was no significant difference in the SOC / OC ratio among the different regions in China studied herein, except for Guiyang, which had a somewhat lower SOC / OC ratio. Moreover, SOC was comprised predominantly of NF sources at all sites (67-89\%), except at Guiyang with values of $42-53 \%$, which are similar to areas in developed countries with good air quality, such as Puy de Dôme, France (86-88\%), and Schauinsland, Germany (84$93 \%$ ) (Gelencsér et al., 2007). However, our values were higher than those of previous studies conducted in China during other winter and spring seasons, indicating the importance of NF to SOC in China during early winter.

\subsection{Comparison of chemicals between samples by $\mathbf{P M}_{2.5}$ concentration}

Two samples, one each with a low and high $\mathrm{PM}_{2.5}$ concentration, were obtained from all 10 study sites (Fig. S1 in the Supplement) for ${ }^{14} \mathrm{C}$ and inorganic ions analysis to investigate the composition of carbonaceous aerosols and evaluate the importance of FF and NF carbon in haze formation across China in early winter. During sampling, the air masses generally moved in a northwesterly to northeasterly direction to reach the site. The 5-day back trajectory analysis revealed relatively lower concentrations of $\mathrm{PM}_{2.5}$ when the wind speed was higher, and relatively higher $\mathrm{PM}_{2.5}$ levels when the wind speed was lower and more stable; synoptic conditions apparently promoted the accumulation of particles (Fig. 3).

Theoretically, the aerosol composition at higher wind speeds should reflect regional background aerosol characteristics. Figure 3 shows the $\mathrm{PM}_{2.5}$ chemical compositions of the stage for lower $\mathrm{PM}_{2.5}$ concentration during sampling period. Here, due to the different conversion factors used to transform WINSOC to WINSOM (1.3) and WSOC to WSOM (2.1), OM calculations were based on the relative contributions of WSOC and WINSOC to OC. TOM is the sum of EC, WINSOM and WSOM. Generally, TOM contributions to $\mathrm{PM}_{2.5}$ ranged from 21 to $38 \%$, except in Guiyang, where a value of $8 \%$ was observed. Moreover, OM was comprised mainly of NF emissions. In cities in northern China (Beijing, Xinxiang and Taiyuan), the contribution of WINSOM (both FF and NF) was greater, indicating that POC played a major role in regional air quality during this season. Simultaneously, the lower $\mathrm{NO}_{3}^{-} / \mathrm{SO}_{4}^{2-}$ ratios also implied that POC from FFs might be derived predominantly from 


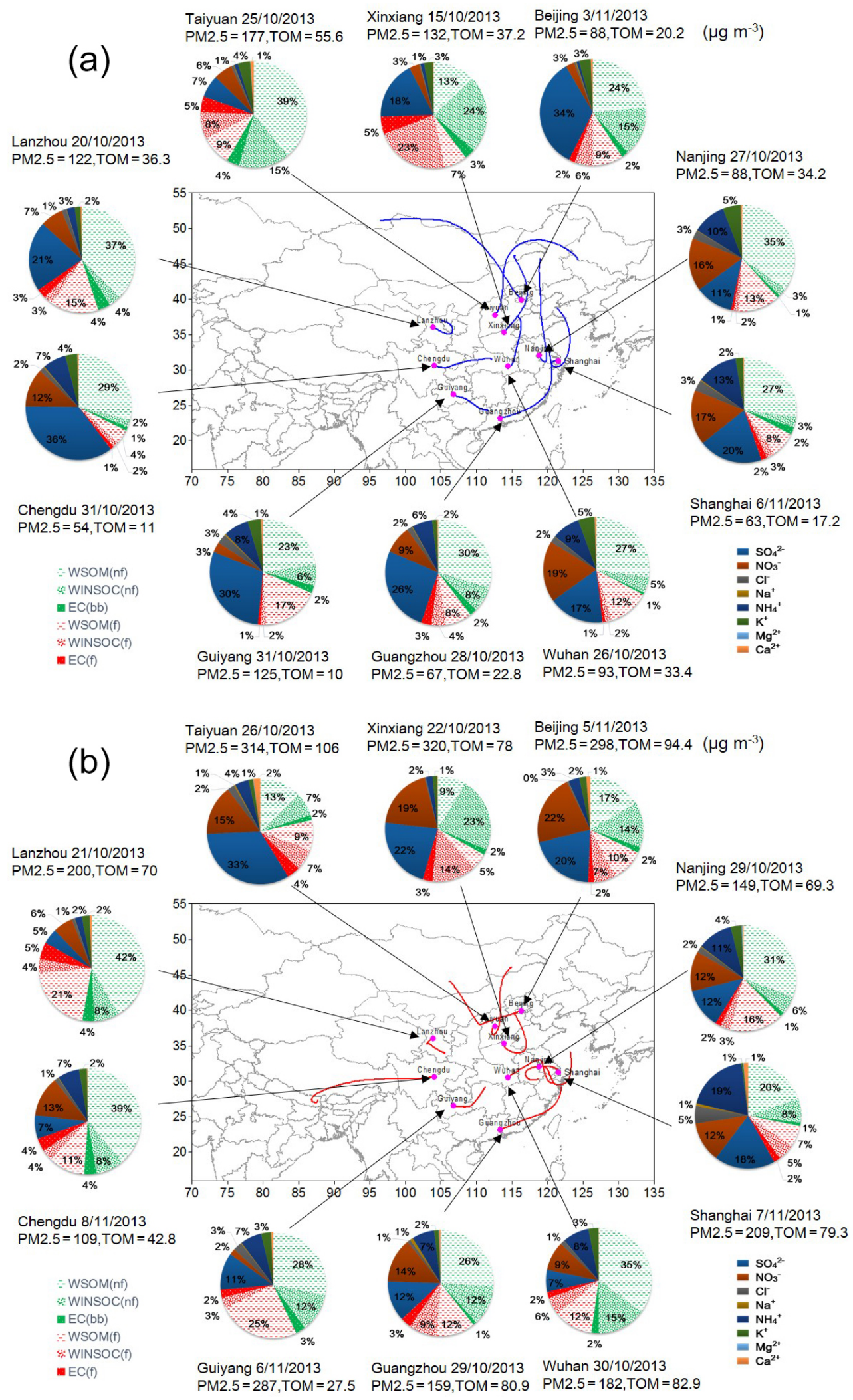

Figure 3. The chemical compositions of fine particles $\left(\mathrm{PM}_{2.5}\right)$ under non-haze (a) and haze (b) conditions during the sampling period. Air mass 5-day back trajectories (blue and red lines) for the selected samples are modeled at $500 \mathrm{~m}$ above ground level by the Air Resources Laboratory, National Oceanic and Atmospheric Administration (Hybrid Single Particle Lagrangian Integrated Trajectory Model). 
coal combustion. The 5-day back trajectory analysis showed that the air mass came from northern China, including regions such as Inner Mongolia and Hebei Province, where the ambient temperature is always below $10^{\circ} \mathrm{C}$ during this season. It is very common for local rural residents to burn coal or biomass fuel to generate heat for their households. Therefore, coal and biomass fuel combustion in northern China might be the major contributor to regional carbonaceous aerosols in northern China during this season. In other cities, WSOM levels in both FF and NF were much higher than those in WINSOM, showing the importance of SOC across China. However, $\mathrm{NO}_{3}^{-} / \mathrm{SO}_{4}^{2-}$ ratios in Shanghai, Nanjing and Wuhan were much higher than in other areas. The back trajectory results showed that the air mass came from northern China or the Yangtze River Delta, implying that traffic exhaust emissions in those regions was more important for carbonaceous aerosol composition.

The chemical compositions of the higher $\mathrm{PM}_{2.5}$ samples obtained in each city are shown in Fig. 3. There were no dramatic changes in the carbon source or composition in any of the cities; however, the contribution of EC and WINSOM to both fossil and NF fuels increased significantly, along with the $\mathrm{NO}_{3}^{-} / \mathrm{SO}_{4}^{2-}$ ratios, indicating the importance of POC from local regions. The back trajectory results showed that wind speeds were moderate and stable, and that synoptic conditions apparently promoted the accumulation of particles derived either from local or regional sources.

\section{Conclusion}

$\mathrm{PM}_{2.5}$ samples were collected continuously from $10 \mathrm{Chi}$ nese urban cities during early winter 2013. $\mathrm{PM}_{2.5}$, OC and EC levels were highest in northern China, with maximum concentrations of $482 \mu \mathrm{g} \mathrm{m}^{-3}$ (Taiyuan, $n=31$ ), $75.9 \mu \mathrm{g} \mathrm{m}^{-3}$ (Taiyuan, $n=31$ ) and $19.3 \mu \mathrm{g} \mathrm{m}^{-3}$ (Beijing, $n=31$ ), respectively. The ${ }^{14} \mathrm{C}$ results, for the lower and higher $\mathrm{PM}_{2.5}$ concentration sample pairs obtained in each city, indicated that, overall, NF emissions constituted a significant proportion of $\mathrm{TC}$ (average $=65 \pm 7 \%$ ) at all sites, i.e., higher than FF sources. Furthermore, about half of the EC was derived primarily from BB (average $=46 \pm 11 \%$ ), and over half of the OC fraction came from NF sources (average $=68 \pm 7 \%$ ). Source apportionment analysis was done using ${ }^{14} \mathrm{C}$ and unique molecular organic tracers. On average, the largest contributor to $\mathrm{TC}$ was $\mathrm{SOC}_{\mathrm{nf}}$, accounting for $46 \pm 7 \%$ of TC, followed by $\mathrm{SOC}_{\mathrm{f}}(16 \pm 3 \%), \mathrm{POC}_{\mathrm{bb}}(13 \pm 5 \%), \mathrm{POC}_{\mathrm{f}}$ $(12 \pm 3 \%), \mathrm{EC}_{\mathrm{f}}(7 \pm 2 \%)$ and $\mathrm{EC}_{\mathrm{bb}}(6 \pm 2 \%)$. When relatively lower $\mathrm{PM}_{2.5}$ concentrations were observed, OM was dominant in carbonaceous aerosols, mainly from NF. POC played a major role in regional air quality in the cities in northern China, while SOC contributed more in cities in other regions of China, such as Nanjing and Wuhan. During haze days, there were no dramatic changes in carbon sources or carbon compositions in the sampled cities, but the contributions of POC were relatively higher than the non-haze days.

Data availability. All data are available upon request from the corresponding author.

\section{The Supplement related to this article is available online at https://doi.org/10.5194/acp-17-11491-2017- supplement.}

Competing interests. The authors declare that they have no conflict of interest.

Acknowledgements. This study was supported by the Guangzhou Science and Technology Plan Projects (no. 201504010002), the Natural Science Foundation of China (NSFC; nos. 41430645, 41473101, 41503092 and 41373131), and the "Strategic Priority Research Program (B)" of the Chinese Academy of Sciences (grant no. XDB05040503). All data in this paper are freely available on request through the corresponding author (junli@gig.ac.cn). This is contribution no. IS-2431 from GIGCAS.

Edited by: Aijun Ding

Reviewed by: two anonymous referees

\section{References}

Barrett, T. E., Robinson, E. M., Usenko, S., and Sheesley, R J.: Source Contributions to Wintertime Elemental and Organic Carbon in the Western Arctic Based on Radiocarbon and Tracer Apportionment, Environ. Sci. Technol., 49, 11631-11639, https://doi.org/10.1021/acs.est.5b03081, 2015.

Bernardoni, V., Calzolai, G., Chiari, M., Fedi, M., Lucarelli, F., Nava, S., Piazzalunga, A., Riccobono, F., Taccetti, F., Valli, G., and Vecchi, R.: Radiocarbon analysis on organic and elemental carbon in aerosol samples and source apportionment at an urban site in Northern Italy, J. Aerosol Sci., 56, 88-99, https://doi.org/10.1016/j.jaerosci.2012.06.001, 2013.

Bove, M. C., Brotto, P., Cassola, F., Cuccia, E., Massabò, D., Mazzino, A., Piazzalunga, A., and Prati, P.: An integrated PM2.5 source apportionment study: Positive Matrix Factorisation vs. the chemical transport model CAMx, Atmos. Environ., 94, 274-286, https://doi.org/10.1016/j.atmosenv.2014.05.039, 2014.

Chen, B., Andersson, A., Lee, M., Kirillova, E. N., Xiao, Q. Kruså, M., Shi, M., Hu, K., Lu, Z., Streets, D. G., Du, K., and Gustafsson, Ö.: Source Forensics of Black Carbon Aerosols from China, Environ. Sci. Technol., 47, 9102-9108, https://doi.org/10.1021/es401599r, 2013.

Choi, J.-K., Heo, J.-B., Ban, S.-J., Yi, S.-M., and Zoh, K.-D.: Chemical characteristics of $\mathrm{PM}_{2.5}$ aerosol in Incheon, Korea, Atmos. Environ., 60, 583-592, https://doi.org/10.1016/j.atmosenv.2012.06.078, 2012.

Colvile, R. N., Gómez-Perales, J. E., and Nieuwenhuijsen, M. J.: Use of dispersion modelling to assess road-user exposure to 
$\mathrm{PM}_{2.5}$ and its source apportionment, Atmos. Environ., 37, 27732782, https://doi.org/10.1016/S1352-2310(03)00217-6, 2003.

Dan, M., Zhuang, G., Li, X., Tao, H., and Zhuang, Y.: The characteristics of carbonaceous species and their sources in $\mathrm{PM}_{2.5}$ in Beijing, Atmos. Environ., 38, 3443-3452, https://doi.org/10.1016/j.atmosenv.2004.02.052, 2004.

Deng, X., Tie, X., Wu, D., Zhou, X., Bi, X., Tan, H., Li, F., and Jiang, C.: Long-term trend of visibility and its characterizations in the Pearl River Delta (PRD) region, China, Atmos. Environ., 42, 1424-1435, https://doi.org/10.1016/j.atmosenv.2007.11.025, 2008.

Ding, X., Zheng, M., Edgerton, E. S., Jansen, J. J., and Wang, X.: Contemporary or Fossil Origin: Split of Estimated Secondary Organic Carbon in the Southeastern United States, Environ. Sci. Technol., 42, 9122-9128, https://doi.org/10.1021/es802115t, 2008.

Docherty, K. S., Stone, E. A., Ulbrich, I. M., DeCarlo, P. F., Snyder, D. C., Schauer, J. J., Peltier, R. E., Weber, R. J., Murphy, S. M., Seinfeld, J. H., Grover, B. D., Eatough, D. J., and Jimenez, J. L.: Apportionment of Primary and Secondary Organic Aerosols in Southern California during the 2005 Study of Organic Aerosols in Riverside (SOAR-1), Environ. Sci. Technol., 42, 7655-7662, https://doi.org/10.1021/es8008166, 2008.

Fine, P. M., Cass, G. R., and Simoneit, B. R.: Chemical characterization of fine particle emissions from fireplace combustion of woods grown in the northeastern United States, Environ. Sci. Technol., 35, 2665-2675, https://doi.org/10.1021/es001466k, 2001.

Fine, P. M., Cass, G. R., and Simoneit, B. R.: Chemical characterization of fine particle emissions from the fireplace combustion of woods grown in the southern United States, Environ. Sci. Technol., 36, 1442-1451, https://doi.org/10.1021/es0108988, 2002.

Fine, P. M., Cass, G. R., and Simoneit, B. R.: Chemical characterization of fine particle emissions from the fireplace combustion of wood types grown in the Midwestern and Western United States, Environ. Eng. Sci., 21, 387-409, https://doi.org/10.1089/109287504323067021, 2004.

Gao, S., Hegg, D. A., Hobbs, P. V., Kirchstetter, T. W., Magi, B. I., and Sadilek, M.: Water-soluble organic components in aerosols associated with savanna fires in southern Africa: Identification, evolution, and distribution, J. Geophys. Res., 108, 8491, https://doi.org/10.1029/2002JD002324, 2003.

Gelencsér, A., May, B., Simpson, D., Sánchez-Ochoa, A., Kasper-Giebl, A., Puxbaum, H., Caseiro, A., Pio, C., and Legrand, M.: Source apportionment of PM2.5 organic aerosol over Europe: Primary/secondary, natural/anthropogenic, and fossil/biogenic origin, J. Geophys. Res., 112, D23S04, https://doi.org/10.1029/2006JD008094, 2007.

Gnauk, T., Brüggemann, E., Müller, K., Chemnitzer, R., Rüd, C., Galgon, D., Wiedensohler, A., Acker, K., Auel, R., Wieprecht, W., Möller, D., Jaeschke, W., and Herrmann, H.: Aerosol characterisation at the FEBUKO upwind station Goldlauter (I): Particle mass, main ionic components, OCEC, and mass closure, Atmos. Environ., 39, 4209-4218, https://doi.org/10.1016/j.atmosenv.2005.02.007, 2005.

He, H., Wang, Y., Ma, Q., Ma, J., Chu, B., Ji, D., Tang, G., Liu, C., Zhang, H., and Hao, J.: Mineral dust and NOx promote the conversion of $\mathrm{SO}_{2}$ to sulfate in heavy pollution days, Scientific Reports, 4, 4172, https://doi.org/10.1038/srep04172, 2014.
He, L.-Y., Hu, M., Zhang, Y.-H., Huang, X.-F., and Yao, T.-T.: Fine Particle Emissions from On-Road Vehicles in the Zhujiang Tunnel, China, Environ. Sci. Technol., 42, 4461-4466, https://doi.org/10.1021/es7022658, 2008.

He, Z., Kim, Y. J., Ogunjobi, K. O., Kim, J. E., and Ryu, S. Y.: Carbonaceous aerosol characteristics of $\mathrm{PM}_{2.5}$ particles in Northeastern Asia in summer 2002, Atmos. Environ., 38, 1795-1800, https://doi.org/10.1016/j.atmosenv.2003.12.023, 2004.

Hedberg, E., Johansson, C., Johansson, L., Swietlicki, E., and Brorström-Lundén, E.: Is levoglucosan a suitable quantitative tracer for wood burning? Comparison with receptor modeling on trace elements in Lycksele, Sweden, J. Air Waste Manage., 56, 1669-1678, https://doi.org/10.1080/10473289.2006.10464572, 2006.

Huang, R.-J., Zhang, Y., Bozzetti, C., Ho, K.-F., Cao, J.-J., Han, Y., Daellenbach, K. R., Slowik, J. G., Platt, S. M., Canonaco, F., Zotter, P., Wolf, R., Pieber, S. M., Bruns, E. A., Crippa, M., Ciarelli, G., Piazzalunga, A., Schwikowski, M., Abbaszade, G., SchnelleKreis, J., Zimmermann, R., An, Z., Szidat, S., Baltensperger, U., Haddad, I. E., and Prévôt, A. S. H.: High secondary aerosol contribution to particulate pollution during haze events in China, Nature, 514, 218-222, https://doi.org/10.1038/nature13774, 2014.

Kam, W., Liacos, J. W., Schauer, J. J., Delfino, R. J., and Sioutas, C.: Size-segregated composition of particulate matter (PM) in major roadways and surface streets, Atmos. Environ., 55, 90-97, https://doi.org/10.1016/j.atmosenv.2012.03.028, 2012.

Kanakidou, M., Seinfeld, J. H., Pandis, S. N., Barnes, I., Dentener, F. J., Facchini, M. C., Van Dingenen, R., Ervens, B., Nenes, A., Nielsen, C. J., Swietlicki, E., Putaud, J. P., Balkanski, Y., Fuzzi, S., Horth, J., Moortgat, G. K., Winterhalter, R., Myhre, C. E. L., Tsigaridis, K., Vignati, E., Stephanou, E. G., and Wilson, J.: Organic aerosol and global climate modelling: a review, Atmos. Chem. Phys., 5, 1053-1123, https://doi.org/10.5194/acp-5-10532005, 2005.

Kim, Y. P., Moon, K. C., and Hoon Lee, J.: Organic and elemental carbon in fine particles at Kosan, Korea, Atmos. Environ., 34, 3309-3317, https://doi.org/10.1016/S1352-2310(99)00445$8,2000$.

Kleefeld, S., Hoffer, A., Krivácsy, Z., and Jennings, S. G.: Importance of organic and black carbon in atmospheric aerosols at Mace Head, on the West Coast of Ireland $\left(53^{\circ} 19^{\prime} \mathrm{N}, 9^{\circ} 54^{\prime} \mathrm{W}\right)$, Atmos. Environ., 36, 4479-4490, https://doi.org/10.1016/S13522310(02)00346-1, 2002.

Krivácsy, Z., Hoffer, A., Sárvári, Z., Temesi, D., Baltensperger, U., Nyeki, S., Weingartner, E., Kleefeld, S., and Jennings, S. G.: Role of organic and black carbon in the chemical composition of atmospheric aerosol at European background sites, Atmos. Environ., 35, 6231-6244, https://doi.org/10.1016/S13522310(01)00467-8, 2001.

Lee, S., Wang, Y., and Rusell, A. G.: Assessment of secondary organic carbon in the southeastern United States: A review, J. Air Waste Manage., 60, 1282-1292, https://doi.org/10.3155/10473289.60.11.1282, 2010.

Liu, D., Li, J., Zhang, Y. L., Xu, Y., Liu, X., Ding, P., Shen, C. D., Chen, Y. J., Tian, C. G., and Zhang, G.: The Use of Levoglucosan and Radiocarbon for Source Apportionment of $\mathrm{PM}_{2.5}$ Carbonaceous Aerosols at a Background Site in East China, Environ. Sci. Technol., 47, 10454-10461, https://doi.org/10.1021/es401250k, 2013. 
Liu, J., Li, J., Zhang, Y., Liu, D., Ding, P., Shen, C., Shen, K., He, Q., Ding, X., Wang, X., Chen, D., Szidat, S., and Zhang, G.: Source Apportionment Using Radiocarbon and Organic Tracers for $\mathrm{PM}_{2.5}$ Carbonaceous Aerosols in Guangzhou, South China: Contrasting Local- and RegionalScale Haze Events, Environ. Sci. Technol., 48, 12002-12011, https://doi.org/10.1021/es503102w, 2014a.

Liu, J., Xu, Y., Li, J., Liu, D., Tian, C., Chaemfa, C., and Zhang, G.: The distribution and origin of PAHs over the Asian marginal seas, the Indian, and the Pacific Oceans: Implications for outflows from Asia and Africa, J. Geophys. Res.-Atmos., 119, 1949-1961, https://doi.org/10.1002/2013jd020361, 2014b.

Liu, J., Li, J., Vonwiller, M., Liu, D., Cheng, H., Shen, K., Salazer, G., Agrios, K., Zhang, Y., He, Q., Ding, X., Zhong, G., Wang, X., Szidat, S., and Zhang, G.: The importance of non-fossil sources in carbonaceous aerosols in a megacity of central China during the 2013 winter haze episode: A source apportionment constrained by radiocarbon and organic tracers, Atmos. Environ., 144, 60-68, https://doi.org/10.1016/j.atmosenv.2016.08.068, 2016a

Liu, J., Mo, Y., Li, J., Liu, D., Shen, C., Ding, P., Jiang, H., Cheng, Z., Zhang, X., Tian, C., Chen, Y., and Zhang, G.: Radiocarbonderived source apportionment of fine carbonaceous aerosols before, during, and after the 2014 Asia-Pacific Economic Cooperation (APEC) summit in Beijing, China, J. Geophys. Res.-Atmos., 121, 4177-4187, https://doi.org/10.1002/2016jd024865, 2016b.

Liu, X. G., Li, J., Qu, Y., Han, T., Hou, L., Gu, J., Chen, C., Yang, Y., Liu, X., Yang, T., Zhang, Y., Tian, H., and Hu, M.: Formation and evolution mechanism of regional haze: a case study in the megacity Beijing, China, Atmos. Chem. Phys., 13, 4501-4514, https://doi.org/10.5194/acp-13-4501-2013, 2013.

Marcazzan, G. M., Ceriani, M., Valli, G., and Vecchi, R.: Source apportionment of $\mathrm{PM}_{10}$ and $\mathrm{PM}_{2.5}$ in Milan (Italy) using receptor modelling, Sci. Total Environ., 317, 137-147, https://doi.org/10.1016/S0048-9697(03)00368-1, 2003.

Mayol-Bracero, O. L., Guyon, P., Graham, B., Roberts, G., Andreae, M., Decesari, S., Facchini, M., Fuzzi, S., and Artaxo, P.: Water-soluble organic compounds in biomass burning aerosols over Amazonia, 2. Apportionment of the chemical composition and importance of the polyacidic fraction, J. Geophys. Res., 107, 8091, https://doi.org/10.1029/2001JD000522, 2002.

Rattigan, O. V., Dirk Felton, H., Bae, M.-S., Schwab, J. J., and Demerjian, K. L.: Multi-year hourly $\mathrm{PM}_{2 .} 5$ carbon measurements in New York: Diurnal, day of week and seasonal patterns, Atmos. Environ., 44, 2043-2053, https://doi.org/10.1016/j.atmosenv.2010.01.019, 2010.

Robinson, A. L., Donahue, N. M., and Rogge, W. F.: Photochemical oxidation and changes in molecular composition of organic aerosol in the regional context, J. Geophys. Res., 111, D03302, https://doi.org/10.1029/2005JD006265, 2006.

Rogge, W. F., Mazurek, M. A., Hildemann, L. M., Cass, G. R., and Simoneit, B. R. T.: Quantification of urban organic aerosols at a molecular level: Identification, abundance and seasonal variation, Atmos. Environ. A-Gen., 27, 1309-1330, https://doi.org/10.1016/0960-1686(93)90257-Y, 1993.

Simoneit, B. R., Schauer, J. J., Nolte, C., Oros, D. R., Elias, V. O., Fraser, M., Rogge, W., and Cass, G. R.: Levoglucosan, a tracer for cellulose in biomass burning and atmospheric particles,
Atmos. Environ., 33, 173-182, https://doi.org/10.1016/S13522310(98)00145-9, 1999.

Singh, N., Murari, V., Kumar, M., Barman, S. C., and Banerjee, T.: Fine particulates over South Asia: Review and meta-analysis of $\mathrm{PM}_{2.5}$ source apportionment through receptor model, Environ. Pollut., 223, 121-136, https://doi.org/10.1016/j.envpol.2016.12.071, 2017.

Strader, R., Lurmann, F., and Pandis, S. N.: Evaluation of secondary organic aerosol formation in winter, Atmos. Environ., 33, 48494863, https://doi.org/10.1016/S1352-2310(99)00310-6, 1999.

Subramanian, R., Donahue, N. M., Bernardo-Bricker, A., Rogge, W. F., and Robinson, A. L.: Insights into the primary-secondary and regional-local contributions to organic aerosol and $\mathrm{PM}_{2.5}$ mass in Pittsburgh, Pennsylvania, Atmos. Environ., 41, 74147433, https://doi.org/10.1016/j.atmosenv.2007.05.058, 2007.

Sun, Y. L., Jiang, Q., Wang, Z. F., Fu, P. Q., Li, J., Yang, T., and Yin, Y.: Investigation of the sources and evolution processes of severe haze pollution in Beijing in January 2013, J. Geophys. Res.-Atmos., 119, 4380-4398, https://doi.org/10.1002/2014JD021641, 2014.

Szidat, S., Ruff, M., Perron, N., Wacker, L., Synal, H.-A., Hallquist, M., Shannigrahi, A. S., Yttri, K. E., Dye, C., and Simpson, D.: Fossil and non-fossil sources of organic carbon (OC) and elemental carbon (EC) in Göteborg, Sweden, Atmos. Chem. Phys., 9, 1521-1535, https://doi.org/10.5194/acp-9-1521-2009, 2009.

Turpin, B. J. and Huntzicker, J. J.: Identification of secondary organic aerosol episodes and quantitation of primary and secondary organic aerosol concentrations during SCAQS, Atmos. Environ., 29, 3527-3544, https://doi.org/10.1016/1352-2310(94)00276-Q, 1995.

Wang, X., Ding, X., Fu, X., He, Q., Wang, S., Bernard, F., Zhao, X., and Wu, D.: Aerosol scattering coefficients and major chemical compositions of fine particles observed at a rural site in the central Pearl River Delta, South China, J. Environ. Sci., 24, 72-77, https://doi.org/10.1016/S1001-0742(11)60730-4, 2012.

Wang, Y., Wang, M., Zhang, R., Ghan, S. J., Lin, Y., Hu, J., Pan, B., Levy, M., Jiang, J. H., and Molina, M. J.: Assessing the effects of anthropogenic aerosols on Pacific storm track using a multiscale global climate model, P. Natl. Acad. Sci. USA, 111, 6894-6899, https://doi.org/10.1073/pnas.1403364111, 2014.

Weber, R. J., Sullivan, A. P., Peltier, R. E., Russell, A., Yan, B., Zheng, M., de Gouw, J., Warneke, C., Brock, C., Holloway, J. S., Atlas, E. L., and Edgerton, E.: A study of secondary organic aerosol formation in the anthropogenicinfluenced southeastern United States, J. Geophys. Res., 112, D13302, https://doi.org/10.1029/2007JD008408, 2007.

Yang, F., He, K., Ye, B., Chen, X., Cha, L., Cadle, S. H., Chan, T., and Mulawa, P. A.: One-year record of organic and elemental carbon in fine particles in downtown Beijing and Shanghai, Atmos. Chem. Phys., 5, 1449-1457, https://doi.org/10.5194/acp5-1449-2005, 2005.

Yttri, K. E., Simpson, D., Stenström, K., Puxbaum, H., and Svendby, T.: Source apportionment of the carbonaceous aerosol in Norway - quantitative estimates based on ${ }^{14} \mathrm{C}$, thermal-optical and organic tracer analysis, Atmos. Chem. Phys., 11, 9375-9394, https://doi.org/10.5194/acp-11-9375-2011, 2011.

Zhang, Y., Schauer, J. J., Zhang, Y., Zeng, L., Wei, Y., Liu, Y., and Shao, M.: Characteristics of Particulate Carbon Emissions from 
Real-World Chinese Coal Combustion, Environ. Sci. Technol., 42, 5068-5073, https://doi.org/10.1021/es7022576, 2008.

Zhang, Y., Zotter, P., Perron, N., Prévôt, A., Wacker, L., and Szidat, S.: Fossil and non-fossil sources of different carbonaceous fractions in fine and coarse particles by radiocarbon measurement, Radiocarbon, 55, 1510-1520, https://doi.org/10.2458/azu_js_rc.55.16278, 2013.

Zhang, Y., Ren, H., Sun, Y., Cao, F., Chang, Y., Liu, S., Lee, X., Agrios, K., Kawamura, K., Liu, D., Ren, L., Du, W., Wang, Z., Prévôt, A. S. H., Szidat, S., and Fu, P.: High Contribution of Nonfossil Sources to Submicrometer Organic Aerosols in Beijing, China, Environ. Sci. Technol., 51, 7842-7852, https://doi.org/10.1021/acs.est.7b01517, 2017.

Zhang, Y.-L., Li, J., Zhang, G., Zotter, P., Huang, R.-J., Tang, J.-H., Wacker, L., Prévôt, A. S. H., and Szidat, S.: Radiocarbon-Based Source Apportionment of Carbonaceous Aerosols at a Regional Background Site on Hainan Island, South China, Environ. Sci. Technol., 48, 2651-2659, https://doi.org/10.1021/es4050852, 2014.

Zhang, Y.-L., Huang, R.-J., El Haddad, I., Ho, K.-F., Cao, J.-J., Han, Y., Zotter, P., Bozzetti, C., Daellenbach, K. R., Canonaco, F., Slowik, J. G., Salazar, G., Schwikowski, M., Schnelle-Kreis, J., Abbaszade, G., Zimmermann, R., Baltensperger, U., Prévôt, A. S. H., and Szidat, S.: Fossil vs. non-fossil sources of fine carbonaceous aerosols in four Chinese cities during the extreme winter haze episode of 2013, Atmos. Chem. Phys., 15, 1299-1312, https://doi.org/10.5194/acp-15-1299-2015, 2015a.
Zhang, Y.-L., Schnelle-Kreis, J., Abbaszade, G., Zimmermann, R., Zotter, P., Shen, R. R., Schafer, K., Shao, L., Prevot, A. S., and Szidat, S.: Source Apportionment of Elemental Carbon in Beijing, China: Insights from Radiocarbon and Organic Marker Measurements, Environ. Sci. Technol., 49, 8408-8415, https://doi.org/10.1021/acs.est.5b01944, 2015b.

Zhao, X. J., Zhao, P. S., Xu, J., Meng,, W., Pu, W. W., Dong, F., He, D., and Shi, Q. F.: Analysis of a winter regional haze event and its formation mechanism in the North China Plain, Atmos. Chem. Phys., 13, 5685-5696, https://doi.org/10.5194/acp13-5685-2013, 2013.

Zhou, R., Wang, S., Shi, C., Wang, W., Zhao, H., Liu, R., Chen, L., and Zhou, B.: Study on the Traffic Air Pollution inside and outside a Road Tunnel in Shanghai, China, Plos One, 9, e112195, https://doi.org/10.1371/journal.pone.0112195, 2014.

Zong, Z., Wang, X., Tian, C., Chen, Y., Qu, L., Ji, L., Zhi, G., Li, J., and Zhang, G.: Source apportionment of $\mathrm{PM}_{2.5}$ at a regional background site in North China using PMF linked with radiocarbon analysis: insight into the contribution of biomass burning, Atmos. Chem. Phys., 16, 11249-11265, https://doi.org/10.5194/acp-16-11249-2016, 2016. 